https://doi.org/10.5817/OS2019-3-6

\title{
Оломоуцкие дни русистов 2019
}

5-6 сентября 2019 года в Оломоуце (Чешская Республика) состоялась XXV Международная научная конференция «Оломоуцкие дни русистов», организованная кафедрой славистики философского факультета университета им. Палацкого.

Торжественное открытие конференции состоялось в Актовом зале философского факультета. Конференцию открыл приветственным словом декан философского факультета профессор 3. Пехал. Первым докладом, прозвучавшим на конференции, стал доклад А. Ф. Литвиной и Ф. Б. Успенского Мужское vs женское в контексте светской христианской двуименности на Руси XVI-XVII вв.

Далее работа конференции продолжалась в секциях. Несмотря на то, что количество участников по сравнению с прошлыми годами сократилось, программа конференции была чрезвычайно насыщенной.

В литературоведческой секции в этом году основной темой для обсуждений стала проблема конструирования (авто)биографии в русской литературе, которая была рассмотрена в контексте самых разнообразных вопросов: от автобиографичности художественных текстов и субъективности фактов мемуаристики вплоть до построения жизни как автобиографичского проекта или конструирования новой, до сего времени неизвестной свету автобиографии русского сказочника и пр. Особенно хочется отметить продуктивность дискуссий и обсуждений в секции, а также широкий охват авторов, представивших внушительную временную парадигму от средневековья до новейшей русской литературы.

Традиционно на Оломоуцких днях русистов уделяется большое внимание вопросам фразеологии. Этот год не стал исключением, основной темой фразеологической секции стала русская фразеология в европейском контексте.

Работы переводческой секции в основном была посвящена актуальным проблемам перевода специального текста на материале как славянских, так и других языков (английский, немецкий, китайский).

Лингвистическая секция была одной из самых многочисленных, поэтому были организованы 4 подсекции. Главными темами стали вопросы рода, пола, гендера в пространстве языка, культуры, коммуникации, а также современные тенденции в развитии русского языка на фоне динамики славянских языков. Прозвучали доклады, посвященные функционированию языковых единиц на разных языковых уровнях, особое внимание было уделено вопросам терминоведения. Заключительная часть работы в лингвистической секции 
была посвящена актуальной проблеме гендера, причём рассматривалась как лингвистическая, так и социокультурологическая сторона вопроса. Особую дискуссию вызвала проблематика гендера в постлитературе с выходом на актуальные проблемы современности, а также вопрос гендерных ролей в культуре Трёхречья (Китай).

На конференции царила доброжелательная творческая и рабочая атмосфера, мотивирующая к установлению новых контактов с коллегами и обмену опытом. Все участники конференции получили уже изданный сборник тезисов конференции, статьи на тему доклада можно опубликовать в рецензируемом научном журнале Rossica Olomucensia.

Полина Золина, Ольга Бергер

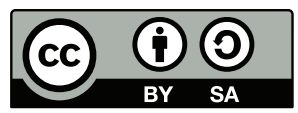

This work can be used in accordance with the Creative Commons BY-SA 4.0 International license terms and conditions (<https://creativecommons.org/licenses/by-sa/4.0/legalcode>). This does not apply to works or elements (such as images or photographs) that are used in the work under a contractual license or exception or limitation to relevant rights.

\section{Студенческие диалоги о Восточной Европе (Брно-Оломоуц-Прага)}

18 октября 2019 года на философском факультете Карлова университета состоялась первая научно-студенческая конференция, посвященная Восточной Европе. На конференции встретились студенты и выпускники магистратуры и докторантуры трех чешских университетов (Университет им. Масарика в Брно, Университет им. Палацкого в Оломоуце, Карлов университет в Праге) и представили результаты своих исследований. Конференция ставит перед собой сразу несколько задач: развить и укрепить преемственность славистических традиций, дать возможность молодым исследователям завязать новые контакты и презентовать свои научные работы, вдохновить ученых на междисциплинарное сотрудничество.

Выступления на конференции была разделены тематически: сначала прозвучали доклады на культурно-исторические темы, далее участники ознакомились с докладами лингвистической проблематики, закрывала работу конференции самая многочисленная по количеству докладов литературоведческая секция. 